\title{
A squamous cell carcinoma of the lower lip with a discoid lupus erythematosus
}

\section{Boubacar Ahy Diatta, Salimatou Diallo, Matar Ndiaye, Silly Touré, Gisèle Wotto Gaye, Mame Thierno Dieng}

Department of Dermatology of the Cheikh Anta Diop University of Dakar, Dakar, Senegal

Corresponding author: Dr. Boubacar Ahy Diatta, E-mail: ahydiatta@yahoo.com

\begin{abstract}
Squamous cell carcinoma (SCC) is a malignant tumor with an estimated prevalence of $0.09 \%$ in Dakar. We report the case of a 40-year-old man with chronic lupus of the lower lip confirmed by histology and treated with topical corticosteroids and synthetic antimalarials for six years. He was hospitalized for an ulcerated and budding tumor of the lower lip evolving for six months whose histological study confirmed a squamous cell carcinoma. Complete surgical resection was performed and safety margins of $1 \mathrm{~cm}$ were excised with lymph node dissection under the mandible. The clinical result was favorable. Early surgical management has improved its prognosis.
\end{abstract}

Key words: Squamous cell carcinoma; Discoid lupus erythematosus; Dakar

\section{INTRODUCTION}

Squamous cell carcinoma (SCC) is a malignant tumor with an estimated prevalence of $0.09 \%$ in Dakar. It most often occurs on preexisting dermatosis, such as discoid lupus erythematosus (DLE) [1]. This autoimmune dermatosis is characterized on the one hand by erythematous-squamous and atrophic lesions on the sun-exposed areas and on the other hand by histopathological alterations such as hyperkeratosis, atrophy of the mucous body of Malpighi, liquefying necrosis of the basal layer, and lymphocytic infiltrate [2]. Lip carcinoma accounts for $8 \%$ of labial dermatoses in Senegal [3]. Its severity is related to the risk of metastasis with fatal evolution and aesthetic damage $[1,4,5]$. We report a case of SCC of the lower lip occurring on a lesion of discoid lupus.

\section{CASE REPORT}

A 40-year-old man, with no history of alcohol or tobacco use, was admitted to the hospital for a tumor of the lower lip that had been evolving in a preexisting lesion six months ago. The previous medical and clinical reports revealed that he has been followed up for six years in a practice of dermatology for DLE of the lower lip and lower limbs, which was confirmed by histology. He received dermocorticoids and synthetic antimalarials for these lesions. Physical examination revealed an ulcerous-budding tumor measuring $3 \mathrm{~cm}$ in diameter associated with an erythematous, squamous, and atrophic plaque on the lower lip (Figs. la and lb). There were also hypopigmented atrophic macules of the lower limbs. The lymph nodes were normal. Histopathology of the lip tumor revealed infiltrated and differentiated squamous cell carcinoma (Figs. 2a and 2b). The serological tests were normal, with leukocytes measured at $7200 / \mathrm{mm}^{3}$, hemoglobin at $14 \mathrm{~g} / \mathrm{dl}$, and blood platelets at $250.103 / \mathrm{mm}^{3}$. Fasting blood glucose was at $1.02 \mathrm{~g} /$. Transaminases, serum electrolytes, blood urea, creatinine clearance, C-reactive protein were also normal. Serology of HIV and viral hepatitis came back negative. A thoracoabdominal scan (computed tomography) was normal. A complete surgical resection was performed, and safety margins of $1 \mathrm{~cm}$ were excised with node dissection under the mandible.

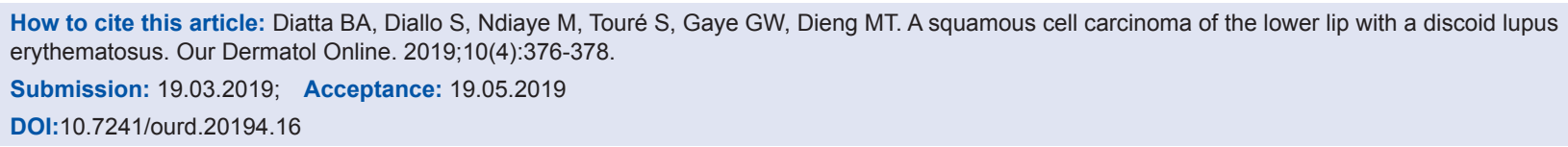


The outcome was favorable.Complete healing was observed without reccurence (Fig. 3). The follow-up period was four years. Histopathological examination of the surgical specimen revealed healthy margins and the absence of metastases in the removed lymph nodes.

Prior to the study, patient gave written consent to the examination and biopsy after having been informed about the procedure.

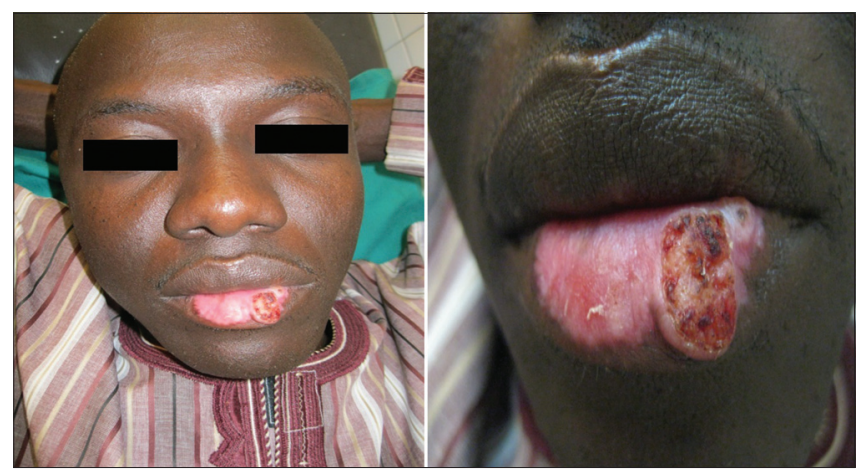

Figure 1: Ulcerated tumor of the lower lip on a lesion of discoid lupus erythematosus.

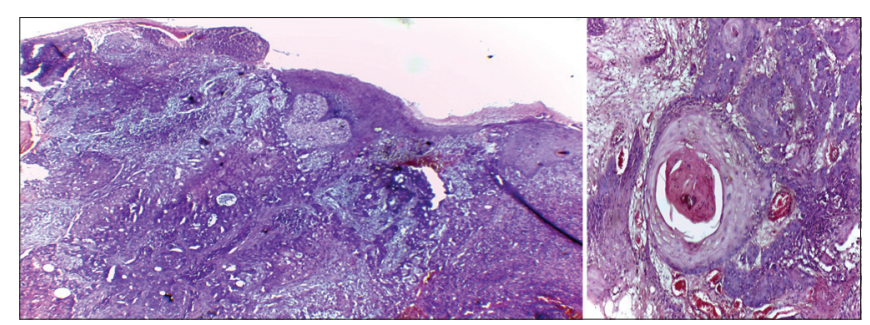

Figure 2: SCC grade1: cell carcinomatous proliferation with welldifferentiated malignant epithelial cells invading the dermis with masses centered by keratin pearls (HE x40, x100).

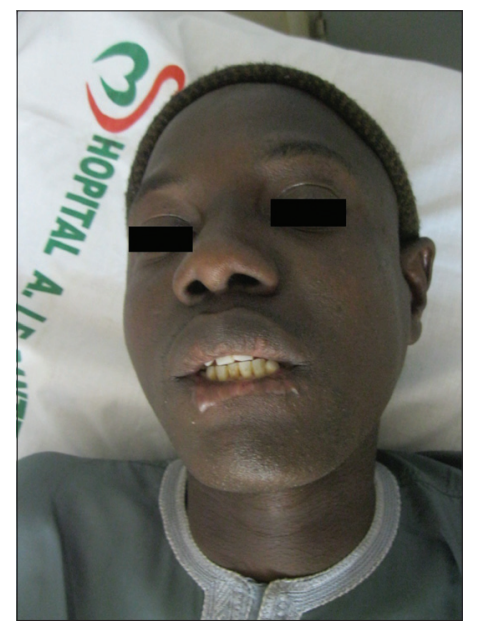

Figure 3: Complete cicatrization after surgical treatment.

\section{DISCUSSION}

In this case study, we report the early diagnosis, successful management, and favorable outcome of a case of squamous cell carcinoma of the lip. SCC can occur on acquired or congenital precancerous lesions. The most frequent of these include burn scars, discoid lupus, leg ulcer, xeroderma pigmentosum, and albinism $[1,5,6]$. Diagnostic delay is often observed in Senegal, resulting in a long duration of evolution that leads to very advanced tumors, thus making curative treatment difficult $[1,3]$. Discoid lupus of the lip constitutes the second most common precancerous dermatosis in Senegal. It is characterized by erythema, scales, and skin atrophy [2]. The pathogenic mechanisms favoring photocarcinogenesis seem to be related to tumor suppressor gene inactivation ( $\mathrm{p} 53$ ). Multiple solar exposures result in inactivation of the p 53 protein, which in turn initiates and promotes the development of carcinoma [7]. The combined action of the repeated solar exposure and the presence of atrophic lupus lesion have contributed to the development of labial carcinoma in our patient $[1,3,7]$. The curative management of labial carcinomas can include major challenges, depending on early diagnosis of the tumor, the tumor's size, conservative surgery, and reconstruction plasties. The factors for good prognosis in our patient were the absence of both metastasis and recurrence after surgical treatment. However, monitoring long-term recurrences must be mandatory $[8,9]$.

\section{CONCLUSION}

Squamous cell carcinoma of the lip is a severe tumor. It can be fatal in advanced forms. Early surgical management of localized tumors can improve the prognosis. Hence, multidisciplinary care for rigorous monitoring of precancerous lesions is important.

\section{Consent}

The examination of the patient was conducted according to the Declaration of Helsinki principles.

\section{REFERENCES}

1. Dieng MT, Diop NN, Déme A, Sy TN, Niang SO, Ndiaye B. Squamous cell carcinoma in black patients: 80 cases. Ann Dermatol Venereol. 2004;131:1055-7.

2. Dieng MT, Ndiaye B. Carcinome épidermoïde sur lupus érythémateux discoïde (Trois Observations). Dakar Med. 2001;46:73-5. 


\section{www.odermatol.com}

3. Niang SO, Diatta BA, Touré S, Niang PD, Coumé M, Kane A. Dermatoses des lèvres. A propos de 72 cas au Sénégal. Rev Sen Odontol Stomatol Chir Maxillo-Fac. 2010;7:11-7.

4. Maïga S, Diom ES, Palou ER, Ndiaye C, Ndiaye M, Dieye A, et al. Epidemiology, clinical features and treatment of lip cancers in Senegal. Health Sci Dis. 2017;18:74-8.

5. Fernandes MS, Girisha BS, Viswanathan N, Sripathi H, Noronha TM. Discoid lupus erythematosus with squamous cell carcinoma: a case report and review of the literature in Indian patients. Lupus. 2015;24:1562-6.

6. Wakisa KM, Fagan J. Squamous cell carcinoma in black patients with discoid lupus erythematosus. S Afr J Surg. 2006;44:144-6.

7. Kim DY, Rha EY, Yoo G, Lim JS. Squamous cell carcinoma on the upper lip of a patient with discoid lupus erythematosus. Arch Plast
Surg. 2013;40:155-7.

8. Gervin CM, McCulla A, Williams M, Ouhtit A. Dysfunction of p53 in photocarcinogenesis. Front Bio sci. 2003;8:715-7.

9. Ee HL, Nq PP, Tan SH, Goh CL. Squamous cell carcinoma developing in two Chinese patients with chronic discoid lupus erythematosus: the need for continued surveillance. Clin Exp Dermatol. 2006;31:542-4.

Copyright by Boubacar Ahy Diatta, et al. This is an open-access article distributed under the terms of the Creative Commons Attribution License, which permits unrestricted use, distribution, and reproduction in any

medium, provided the original author and source are credited.

Source of Support: Nil, Conflict of Interest: None declared. 